\section{Colwellia demingiae sp. nov., Colwellia hornerae sp. nov., Colwellia rossensis sp. nov. and Colwellia psychrotropica sp. nov.: psychrophilic Antarctic species with the ability to synthesize docosahexaenoic acid $(22: 6 \omega 3)$}

\author{
John P. Bowman, ${ }^{1,2}$ John J. Gosink, ${ }^{3}$ Sharee A. McCammon, ${ }^{1}$ \\ Tom E. Lewis, ${ }^{1,2}$ David S. Nichols, ${ }^{1,2}$ Peter D. Nichols, ${ }^{1,4}$ Jenny H. Skerratt, ${ }^{1}$ \\ Jim T. Staley ${ }^{3}$ and Tom A. McMeekin ${ }^{1,2}$
}

1,2 Antarctic $\mathrm{CRC}^{1}$ and Department of Agricultural Science? University of Tasmania, GPO Box 252-80, Hobart, Tasmania 7001, Australia

3 Department of Microbiology, University of Washington, Seattle, WA 98195, USA

${ }^{4}$ CSIRO Marine Research Division, Castray Esplanade, Hobart, Tasmania, 7001, Australia
Author for correspondence: John P. Bowman. Tel: +61362262776 . Fax: +61362262642. e-mail: john.bowman $@$ utas.edu.au

As part of a general survey of the biodiversity and inherent ecophysiology of bacteria associated with coastal Antarctic sea-ice diatom assemblages, eight strains were identified by 165 rRNA sequence analysis as belonging to the genus Colwellia. The isolates were non-pigmented, curved rod-like cells which exhibited psychrophilic and facultative anaerobic growth and possessed an absolute requirement for sea water. One isolate was able to form gas vesicles. All strains synthesized the $\omega 3$ polyunsaturated fatty acid (PUFA) docosahexaenoic acid (22:6 $\omega 3$, DHA) (0.7-8.0\% of total fatty acids). Previously, DHA has only been detected in strains isolated from deep-sea benthic and faunal habitats and is associated with enhanced survival in permanently cold habitats. The $\mathrm{G}+\mathrm{C}$ content of the DNA from the Antarctic Colwellia strains ranged from 35 to $42 \mathrm{~mol} \%$ and DNA-DNA hybridization analyses indicated that the isolates formed five genospecies, including the species Colwellia psychrerythraea (ACAM 550'). 16S rRNA sequence analysis indicated that the strains formed a cluster in the $\gamma$-subclass of the Proteobacteria with Colwellia psychrerythraea. Sequence similarities ranged from 95.2 to $100 \%$ between the various Antarctic Colwellia isolates. Phenotypic characterization confirmed distinct differences between the different genospecies. These studies indicate that the DHA-producing Antarctic isolates consist of five different Colwellia species: Colwellia psychrerythraea and four novel species with the proposed names Colwellia demingiae sp. nov. (ACAM 459'), Colwellia psychrotropica sp. nov. (ACAM 179'), Colwellia rossensis sp. nov. (ACAM 608') and Colwellia hornerae sp. nov. (ACAM 607').

Keywords: Antarctic sea ice, polyunsaturated fatty acids, docosahexaenoic acid, psychrophilic bacteria, Colwellia

\section{INTRODUCTION}

Colwellia-related clones and isolates have been obtained from aggregates of particulate organic material and coastal marine water samples collected offshore of the United States (DeLong et al., 1993;

Abbreviations: $D H A$, docosahexaenoic acid (22:6\%3); EPA, eicosapentaenoic acid (20:5 $(\omega 3)$; PUFA, polyunsaturated fatty acid; TMAO, trimethylamine $\mathrm{N}$-oxide.
Suzuki et al., 1997) and from the Marianas Trench (DeLong \& Yayanos, 1986). Phylogenetic analysis based on 5S (Deming et al., 1984, 1988) and 16S rRNA sequences (DeLong et al., 1993; Gosink \& Staley, 1995; Bowman et al., 1997a) has indicated that this genus is most closely related to other Gram-negative marine genera such as Shewanella, Ferrimonas, Pseudoalteromonas and Alteromonas (Gauthier et al., 1995; Rossello-Móra et al., 1995). Species of the genus Colwellia are facultative anaerobes, characteristically 
psychrophilic (no growth at $20^{\circ} \mathrm{C}$, optimum growth at $<15^{\circ} \mathrm{C}$ ), sometimes barophilic and possess a requirement for elevated sodium and magnesium ions to maintain cell wall and cytoplasmic membrane integrity (D’Aoust \& Kushner, 1972). Recent studies indicate that strains of Colwellia and [Vibrio] marinus synthesize $\omega 3$ polyunsaturated fatty acids (PUFAs), in particular

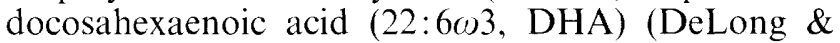
Yayanos, 1986; DeLong et al., 1997). PUFAs such as DHA and eicosapentaenoic acid (20:5 03 , EPA) are essential for human and animal health in a variety of ways. For example, PUFAs are believed to lower the levels of blood plasma cholesterol and triacylglycerols, prevent cardiovascular disease and reduce the risk of some cancers (Kelly, 1991). They are also required for normal embryonic development, particularly optical and neural development (Craigschmidt et al., 1996; Farkas et al., 1996; Linko \& Hayakawa, 1996). $\omega 3$ PUFAs are important food supplements for rearing larval fish in the aquaculture industry. In most cases fish obtain PUFA from 'live feed', including rotifers or Artemia spp. fed on PUFA-rich microalgae, or from PUFA-amended artificial feed (Ostrowski \& Divakaran, 1990; Southgate \& Lou, 1995). Bacteria are recognized as an alternative source of PUFAs for the development of less expensive aquaculture fish feeds (Nichols et al., 1996).

Currently, the genus Colwellia contains two species: Colwellia psychroerythrus and Colwellia hadaliensis (Deming et al., 1988). Colwellia psychroerythrus was named following the observation that the species 'Vibrio psychroerythrus' (D'Aoust \& Kushner, 1972) was phylogenetically distinct from the rest of the genus Vibrio (Deming et al., 1988). The obligately barophilic species Colwellia hadaliensis was also described at that time. The epithet psychroerythrus has been changed to psychrerythraea (L. adj. erythraeus, $-a,-u m$ red) as the name Colwellia is feminine (Euzéby, 1998).

Recently, it was found that a number of Antarctic fast sea-ice isolates and a single strain from an Antarctic meromictic marine salinity lake belonged to the genus Colwellia (Bowman et al., 1997a). In addition, a gasvesicle-forming isolate from the ice/water interface of sea ice in McMurdo Sound, Antarctica, was also shown to be closely related to Colwellia psychrerythraea (Gosink \& Staley, 1995). In this study, these isolates were investigated and found to represent several novel species of the genus Colwellia: Colwellia demingiae sp. nov., Colwellia rossensis sp. nov., Colwellia hornerae sp. nov. and Colwellia psychrotropica sp. nov. All species of the genus Colwellia were found to form DHA, the level of which increases with decreasing optimum growth temperature and possibly represents an adaptation to continually cold marine environments.

\section{METHODS}

Bacterial strains. The strains investigated in this study (Table 1) were routinely grown at $5-10^{\circ} \mathrm{C}$ on marine 2216 agar
(Difco) or on R2A agar (Oxoid) prepared with sea water salts (Ocean Nature, Aquasonic).

Phenotypic characterization. Most of the phenotypic tests used in this study have been described previously (Bowman et al., 1997b). Sodium, magnesium and calcium ion requirement was tested in a basal medium derived from marine 2216 agar containing (per litre distilled water) $5 \mathrm{~g}$ Bacto peptone, $2 \mathrm{~g}$ yeast extract and $10 \mathrm{mg}$ ferric phosphate. Chloride salts were tested at concentrations found typically in sea water: $0.4 \mathrm{M} \mathrm{NaCl}, 25 \mathrm{mM} \mathrm{MgCl}_{2}$ and $8 \mathrm{mM} \mathrm{CaCl}_{2}$ (ZoBell, 1946).

Dissimilatory iron reduction was tested in a medium adapted from Widdel \& Bak (1992) and prepared using the Hungate technique (Hungate, 1968). The medium was prepared with artificial sea water and contained $10 \mathrm{mM}$ amorphic ferric oxide/neutralized ferric chloride or $10 \mathrm{mM}$ soluble ferric oxide/ferric pyrophosphate (Lovely \& Phillips, 1986) as the electron acceptors and $10 \mathrm{mM}$ sodium acetate as the electron donor and carbon source. Uninoculated controls lacking the iron electron acceptors were also prepared. Iron reduction was confirmed by the appearance of a black precipitate (magnetite) and by use of the Merckoquant Iron Test (Merck).

Anaerobic growth with $10 \mathrm{mM}$ trimethylamine $\mathrm{N}$-oxide (TMAO) was tested in mineral salts medium containing (per litre sea water) $2 \mathrm{~g}$ ammonium chloride, $2 \mathrm{mM}$ potassium phosphate buffer, $\mathrm{pH} 7 \cdot 0,2 \mathrm{ml} \mathrm{SL}-10$ trace element solution (Overmann \& Pfennig, 1989), $1 \mathrm{~g}$ yeast extract and $10 \mathrm{ml}$ vitamin solution no. 6 (Staley et al., 1992). The medium $\mathrm{pH}$ was adjusted to 7.0 using $1 \mathrm{M} \mathrm{KOH}$ and was solidified with $1.3 \%(\mathrm{w} / \mathrm{v})$ purified agar (Oxoid). Sodium acetate $(20 \mathrm{mM})$ was used as the electron donor and carbon source. Plates were incubated in an anaerobic jar using Anaerogen Gaspaks (Oxoid). Growth on the plates was compared with control plates lacking TMAO.

Additional biochemical tests were performed using the API $20 \mathrm{E}$ test kit (bioMérieux) prepared according to the manufacturer's specifications except that bacterial strains were suspended in chilled artificial sea water. Carbon and energy source screening utilized a $0 \cdot 1 \%$ concentration of test compounds, except carbohydrates, which were tested at a concentration of $0.2 \%$. The basal medium used was the same as for the TMAO reduction test. Media lacking a carbon source were prepared as negative controls to account for any background growth.

Growth rate analysis. The growth rates of strains ACAM 605, ACAM $607^{\mathrm{T}}$ and ACAM $179^{\mathrm{T}}$ were determined in a temperature gradient incubator (Toyokagaku Sangyo). The temperature gradient used ranged from 0 to $20-27^{\circ} \mathrm{C}$ and tubes, containing $10 \mathrm{ml}$ marine 2216 broth, were inoculated with $0.5 \mathrm{ml}$ cells taken from cultures in late-exponential growth phase. Growth was measured by a decrease in transmittance at $550 \mathrm{~nm}$ for up to $14 \mathrm{~d}$. Growth was considered to have occurred if the culture transmittance decreased by more than $20 \%$. The data were fitted to the square-root growth model of Ratkowsky et al. (1983) and cardinal temperatures determined.

Whole-cell fatty acid analysis. Representative strains were grown on marine 2216 agar at $10^{\circ} \mathrm{C}$ for $2-7 \mathrm{~d}$, harvested into a small amount of artificial sea water and then lyophilized using a vacuum freeze-drier (Dynavac). Profiles of total extractable fatty acids were quantitatively determined using GC and GC-MS procedures (Nichols et al., 1993). The geometry and position of double bonds in monounsaturated fatty acids was confirmed using dimethyl- 
Table 1. Colwellia strains and reference strains investigated in this study

\begin{tabular}{|lcll|}
\hline Received as* & ACAM No. & \multicolumn{1}{c|}{ Name } & \multicolumn{1}{c|}{ Isolation site } \\
\hline ATCC $27364^{\mathrm{T}}$ & $550^{\mathrm{T}}$ & Colwellia psychrerythraea & Flounder eggs \\
IC062 & 604 & Colwellia psychrerythraea & Sea ice, Prydz Bay, Antarctica \\
IC064 & - & Colwellia psychrerythraea & Sea ice, Prydz Bay, Antarctica \\
IC072 & 605 & Colwellia psychrerythraea & Sea ice, Prydz Bay, Antarctica \\
ACAM 179 & $179^{\mathrm{T}}$ & Colwellia psychrotropica sp. nov. & Burton Lake pycnocline, Antarctica \\
ICP11 & $459^{\mathrm{T}}$ & Colwellia demingiae sp. nov. & Sea ice, Prydz Bay, Antarctica \\
IC068 & 606 & Colwellia demingiae sp. nov. & Sea ice, Prydz Bay, Antarctica \\
IC035 & $607^{\mathrm{T}}$ & Colwellia hornerae sp. nov. & Sea ice, Ellis Fjord, Antarctica \\
S51-W $(\mathrm{gv}) 1^{\mathrm{T}}$ & $608^{\mathrm{T}}$ & Colwellia rossensis sp. nov. & Sea ice, McMurdo Sound, Antarctica \\
\hline
\end{tabular}

* ATCC, American Type Culture Collection, Rockville, MD, USA; ACAM, Australian Collection of Antarctic Micro-organisms, Antarctic Cooperative Research Centre, University of Tasmania, Hobart, Tasmania, Australia.

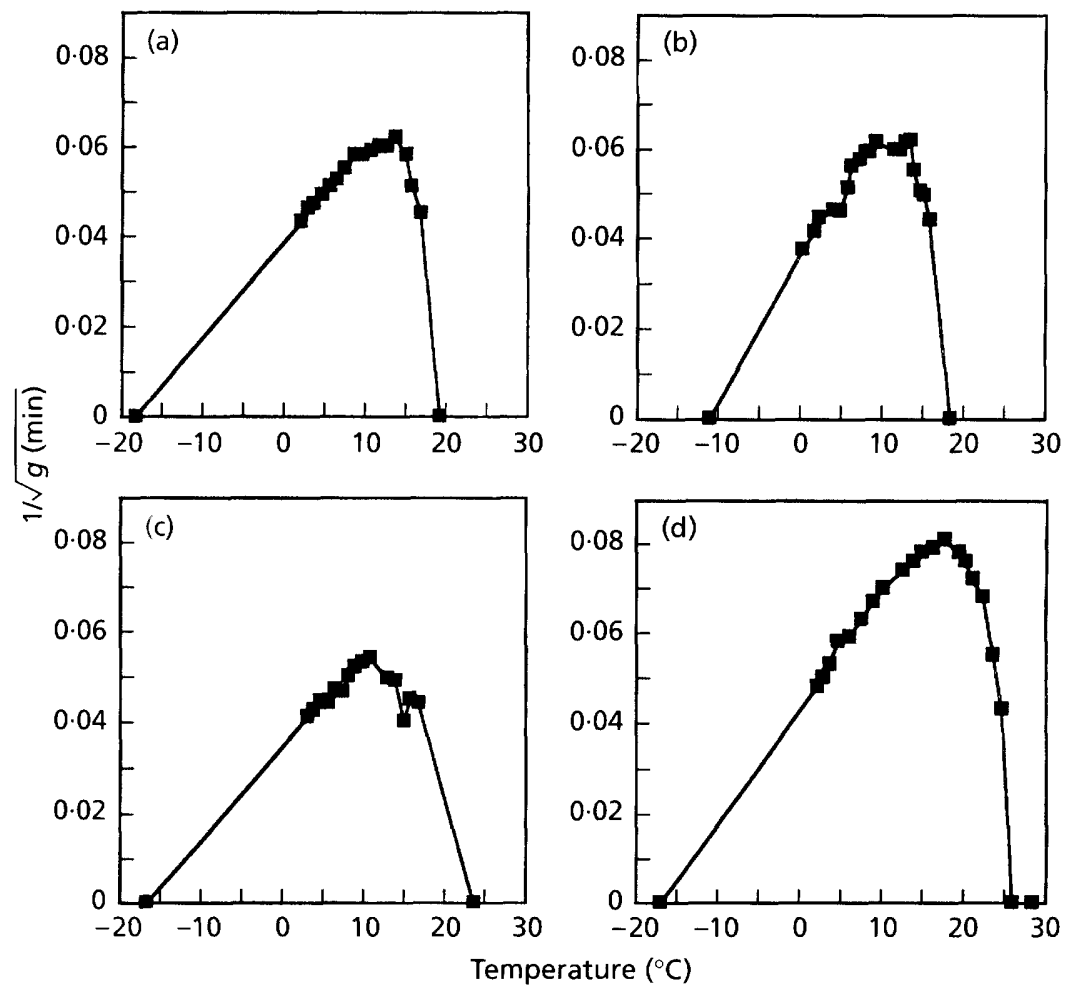

Fig. 1. Temperature growth curves of four
Antarctic Colwellia species based on the
square-root growth model of Ratkowsky
et al. (1983). (a) Colwellia psychrerythraea
ACAM 605, (b) Colwellia demingiae ACAM
$459^{\top}$, (c) Colwellia hornerae ACAM $607^{\top}$ and
(d) Colwellia psychrotropica ACAM $179^{\top}$.
Baseline points ( $T_{\min \text { and } T_{\max } \text { ) were }}$
extrapolated from the growth model.

disulfide derivatization and GC-MS analysis (Nichols et al., 1986). The double bond positions are numbered from the methyl $(\omega)$ end of the fatty acid.

DNA base composition. Cells were grown in the same way as for fatty acid analysis. Genomic DNA was extracted and purified using the procedure of Marmur \& Doty (1962). The DNA $\mathrm{G}+\mathrm{C}$ content was then determined from thermal denaturation profiles (Sly et al., 1986).

DNA-DNA hybridization. The spectrophotometric renaturation rate kinetic procedure, as adapted by Huss et al. (1983), was used to determine DNA-DNA reassociation values between genomic DNA of different strains. Genomic DNA was sheared to a mean size of $1 \mathrm{~kb}$ by sonication, dialysed overnight at $4^{\circ} \mathrm{C}$ in $2 \times$ SSC buffer $(2 \times$ SSC is $0.3 \mathrm{M} \mathrm{NaCl} .0 .03 \mathrm{M}$ sodium citrate, $\mathrm{pH} 7.0$ ) and adjusted in concentration to approximately $75 \mu \mathrm{g} \mathrm{ml}^{-1}$. Following denaturation of the DNA samples, hybridization was performed at the optimum temperature for renaturation $\left(T_{\text {or }}\right)$ which was $25^{\circ} \mathrm{C}$ below the DNA melting temperature and was calculated from the equation: $T_{\text {or }}\left({ }^{\circ} \mathrm{C}\right)=$ $48 \cdot 5+(0 \cdot 41 \times \% \mathrm{G}+\mathrm{C})$. The decreases in absorbance over a 40 min interval of DNA mixtures and control DNA samples were used to calculate DNA hybridization values from the equation: DNA hybridization $(\%)=(4 A B-A-B / 2 \sqrt{ }$ $\overline{(A \times B)}) \times 100$ (Huss et al., 1983), where $A$ and $B$ represent the change in absorbance for two DNA samples being compared and $A B$ represents the change in absorbance for equimolar mixtures of $\mathrm{A}$ and $\mathrm{B}$. DNA hybridization values equal to or below $25 \%$ are considered to represent background hybridization and are thus not considered significant (Huss et al., 1983).

Phylogenetic analysis. The 16S rRNA sequences for the Antarctic Colwellia strains have been determined previously (Gosink \& Staley, 1995; Bowman et al., 1997a). The 
Table 2. Phenotypic properties differentiating Colwellia psychrerythraea and novel Antarctic Colwellia species

+ , All strains positive for test; $v+$, variable reactions for test, type strain is positive; $v-$, variable reactions for test, type strain is negative; - , all strains negative for test; $\mathrm{W}$, weak or delayed reaction; $\mathrm{F}$, acid (but no gas) was formed from these substrates in Leifson oxidation/fermentation medium; NG, no growth occurred on test medium.

\begin{tabular}{|c|c|c|c|c|c|}
\hline Characteristic* & $\begin{array}{c}\text { Colwellia } \\
\text { psychrerythraea }\end{array}$ & $\begin{array}{l}\text { Colwellia } \\
\text { demingiae }\end{array}$ & $\begin{array}{l}\text { Colwellia } \\
\text { rossensis }\end{array}$ & $\begin{array}{l}\text { Colwellia } \\
\text { hornerae }\end{array}$ & $\begin{array}{c}\text { Colwellia } \\
\text { psychrotropica }\end{array}$ \\
\hline Prodigiosin-like pigments & $\mathrm{v}+$ & - & - & - & - \\
\hline Toleration of $200 \%$ sea salts & $v-$ & - & - & + & + \\
\hline Susceptibility to vibriostatic agent $\mathrm{O} / 129\left(100 \mu \mathrm{g} \mathrm{ml}^{-1}\right)$ & $\mathrm{v}-$ & - & - & + & - \\
\hline \multicolumn{6}{|l|}{ Hydrolysis of: } \\
\hline Urea & $v+$ & - & + & - & + \\
\hline Uric acid & - & - & - & - & + \\
\hline Tween 80 & + & - & NG & + & + \\
\hline Casein & + & + & - & + & + \\
\hline Gelatin & $v+$ & - & - & - & - \\
\hline Aesculin & + & + & NG & + & - \\
\hline Chitin & $+F$ & $+\mathbf{F}$ & $+\mathrm{F}$ & - & $+\mathrm{F}$ \\
\hline Starch & + & + & + & + & - \\
\hline Tyrosine & $v-w$ & - & - & - & $+\dagger$ \\
\hline \multicolumn{6}{|l|}{ Production of acid from: } \\
\hline L-Rhamnose & - & - & - & $+\mathrm{F}$ & - \\
\hline D-Glucose & $+F$ & - & $+\mathrm{F}$ & - & - \\
\hline D-Galactose & - & - & + & - & - \\
\hline$N$-Acetylglucosamine & $+F$ & $+\mathbf{F}$ & $+\mathrm{F}$ & - & $+F$ \\
\hline Cellobiose & $v+w$ & - & - & - & - \\
\hline Maltose & $+\mathrm{F}$ & - & - & - & - \\
\hline Glycerol & - & - & + & + & - \\
\hline \multicolumn{6}{|l|}{ Utilization of: } \\
\hline D-Glucose & $\mathrm{v}+$ & - & + & - & - \\
\hline L-Arabinose, D-fructose, D-gluconate & - & - & + & - & - \\
\hline$N$-Acetylglucosamine & + & + & + & - & + \\
\hline Glycerol & - & - & + & + & - \\
\hline Glycogen & + & $v-$ & + & - & - \\
\hline Propionate & $v-$ & + & - & + & - \\
\hline Isobutyrate & - & $v+$ & - & - & + \\
\hline Valerate, caproate, $\gamma$-aminobutyrate & - & + & + & + & + \\
\hline Heptanoate & - & $\mathrm{v}+$ & - & + & - \\
\hline Caprylate & - & $v+$ & - & - & - \\
\hline Malonate & - & $v+$ & + & - & - \\
\hline Glutarate & - & + & - & + & - \\
\hline Azelate & - & $v+$ & - & + & - \\
\hline Citrate & - & + & + & + & - \\
\hline 2-Oxoglutarate & - & - & - & - & + \\
\hline 3-Hydroxybutyrate & + & - & + & - & + \\
\hline L-Malate & - & - & + & - & + \\
\hline DL-Lactate & $v+$ & + & - & + & + \\
\hline Oxaloacetate & + & + & - & + & + \\
\hline L-Alanine, L-aspartate & - & $v+$ & + & - & + \\
\hline L-Asparagine & - & + & + & - & + \\
\hline L-Phenylalanine & - & $v+$ & - & - & - \\
\hline Hydroxy-L-proline & - & $v+$ & - & + & - \\
\hline L-Serine & - & + & - & - & - \\
\hline
\end{tabular}

* The following tests were positive for all strains: catalase, cytochrome- $c$ oxidase, nitrate reduction, alkaline phosphatase, growth at $0-15{ }^{\circ} \mathrm{C}$ and utilization of acetate, butyrate, succinate, fumarate, pyruvate, L-glutamate and L-proline as sole sources of carbon and energy. The following tests were all negative: Fe(III) reduction; TMAO reduction, growth on $0-25 \%$ sea salts or $\geqslant 400 \%$ sea salts, hydrolysis of ONPG, DNA and dextran, arginine dihydrolase, lysine decarboxylase and ornithine decarboxylase activity, production of indole from L-tryptophan, $\mathrm{H}_{2} \mathrm{~S}$ production, production of acid from arabinose, xylose, melibiose, fructose, lactose, mannitol, sorbitol, inositol, mannose, sucrose and trehalose, and utilization of D-galactose, D-xylose, cellobiose, lactose, maltose, D-melibiose, trehalose, sucrose, L-raffinose, D-adonitol, D-arabitol, $m$-inositol, D-mannitol, D-sorbitol, D-gluconate, D-glucuronate, saccharate, $\alpha$ glycerophosphate, isovalerate, nonanoate, adipate, pimelate, aconitate, L-threonine, L-valine and putrescine.

$\dagger$ Brown diffusible pigment formed during L-tyrosine hydrolysis. 
nucleotide sequences were $1373-1503$ bases long and stretched between positions 8 and 1508 (Escherichia coli numbering). Sequence data were manually aligned to various $16 \mathrm{~S}$ rRNA sequences of representatives of the $\gamma$-subclass of the Proteobacteria. Software from PHYLIP version $3.57 \mathrm{c}$ (Felsenstein, 1993) was used to further analyse the sequence data set. DNADIST (using the maximum likelihood option) was used to determine sequence similarities and NEIGHBOR (using the neighbourliness option) to create a phylogenetic tree. The $16 \mathrm{~S}$ rRNA sequence of Marinobacter hydrocarbonoclasticus was used as the outgroup. Reference sequences utilized in the phylogenetic analysis were obtained directly from GenBank and included aggregate clone AGG53 (accession no. L10950), Alteromonas macleodii IAM $12920^{\mathrm{T}} \quad$ (X82145), Colwellia-like strain $\mathrm{S} 51-\mathrm{W}(\mathrm{gv}) 1^{\mathrm{T}}=$ ACAM 608 (U14581); barophilic Colwellia sp. MT41

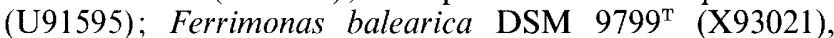
Pseudoalteromonas haloplanktis ATCC 14393' (X67024), Shewanella putrefaciens ATCC 8071 ${ }^{\mathrm{T}}$ (X82123), Marinobacter hydrocarbonoclasticus ATCC $49840^{\mathrm{T}}$ (X67022) and [Vibrio] marinus ATCC $15381^{\mathrm{T}} \quad$ (X82142). Sequences obtained from the study of Bowman et al. (1997a) and utilized in this study include the following: Colwellia psychrerythraea ACAM 550 ${ }^{\mathrm{T}}$ (AF001375), Colwellia sp. ACAM 604 (U85841), Colwellia sp. IC064 (U85842), Colwellia sp. ACAM 605 (U85843), Colwellia sp. ACAM

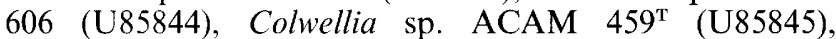
Colwellia sp. ACAM 179 (U85846) and Colwellia sp. ACAM $607^{\mathrm{T}}$ (U85847).

\section{RESULTS}

\section{Growth and morphological characteristics}

Most of the Colwellia strains investigated were psychrophilic when grown on agar medium, unable to grow at $20^{\circ} \mathrm{C}$. Selected strains (ACAM 179 $459^{\mathrm{T}}$, ACAM 605 and ACAM $607^{\mathrm{T}}$ ) were investigated in more detail with cardinal growth temperatures determined using the square-root growth model (Fig. 1). In liquid medium the cardinal growth temperatures were higher than what could be estimated from growth on agar medium. The optimum growth temperatures $\left(T_{\text {opt }}\right.$ ) ranged from 10 to $18^{\circ} \mathrm{C}$. ACAM $179^{\mathrm{T}}$ proved to be the most thermotolerant strain, growing at $25^{\circ} \mathrm{C}$ in liquid medium and at $20^{\circ} \mathrm{C}$ on solid medium. In liquid medium the maximum growth temperature $\left(T_{\max }\right)$ values of the other strains fell between 18 and $23^{\circ} \mathrm{C}$. Theoretical minimum growth temperature $\left(T_{\min }\right)$ values ranged from -10 to $-20^{\circ} \mathrm{C}$, similar to $T_{\min }$ values found for other psychrophiles such as Shewanella spp. (Nichols \& Russell, 1996; Bowman et al., 1997b) and Psychrobacter spp. (Bowman et al., 1996).

All strains possessed a requirement for sea salts, with no growth occurring if the sea salt concentration was less than $25 \%$. ACAM $179^{\mathrm{T}}$ was more halotolerant than the other isolates and grew in the presence of three times the normal concentration of sea salts, while most other strains failed to grow at sea salt concentrations two times greater than normal. Scanty or no growth occurred in medium with $\mathrm{NaCl}$ added alone. The best growth occurred when sodium, magnesium and calcium ions (chloride salts) were added at concentrations typical for sea water.

Except for ACAM $608^{\mathrm{T}}$, all strains investigated were motile and the morphology of the cells varied from spherical to curved to straight rod-shaped cells with occasional short filaments also present. Strain ACAM $608^{\mathrm{T}}$ was the only strain that appeared capable of forming gas vesicles (Gosink \& Staley, 1995). Colwellia psychrerythraea ACAM $550^{\mathrm{T}}$ produced a prodigiosinlike, brilliant red compound which increased in concentration in cells during the exponential growth stage (D'Aoust \& Kushner, 1972). Other strains did not produce pigments. The colonial morphology of the Antarctic strains were similar, forming chalk-white to off-white convex colonies, possessing a low or raised elevation, with entire to lobate edges and butyrous consistency.

\section{Biochemical and nutritional characteristics}

All strains were facultative anaerobes able to grow by fermentation of a suitable carbohydrate as indicated by acid production in Leifson oxidation/fermentation medium. No gas was detected during fermentation. Carbohydrate oxidation and fermentation varied between strains with $N$-acetylglucosamine, chitin and Dglucose being the preferred substrates (Table 2). All of the strains were capable of nitrate reduction. Anaerobic growth by dissimilatory $\mathrm{Fe}(\mathrm{III})$ and TMAO reduction was not observed. Most strains were chitinolytic and able to degrade starch (Table 2). The strains varied somewhat in the hydrolysis of other substrates. For instance, only ACAM $179^{\mathrm{T}}$ was capable of degrading uric acid (Table 2). Most of the strains examined did not require an organic nitrogen source, amino acids or vitamins for growth; however, ACAM $608^{\mathrm{T}}$ required yeast extract $(0 \cdot 1 \%)$ for good growth. The addition of a vitamin solution resulted in an observable stimulation of growth for most of the strains. As a result, carbon utilization studies were performed in a medium supplemented with yeast extract and vitamins. Results for the carbon source utilization tests are shown in Table 2.

\section{Genotypic analyses}

The DNA $\mathrm{G}+\mathrm{C}$ content of the Colwellia isolates ranged from 35 to $42 \mathrm{~mol} \%$ (Table 3 ). DNA-DNA hybridization indicated the presence of five genospecies amongst the strains investigated (Table 3): 1 , Colwellia psychrerythraea (strains ACAM 550 ${ }^{\mathrm{T}}$, ACAM 604, ACAM 605 and IC064); 2, strains ACAM 459 ${ }^{\mathrm{T}}$ and ACAM 606 (Colwellia demingiae); 3, strain ACAM $608^{\mathrm{T}}$ (Colwellia rossensis); 4, strain ACAM $607^{\mathrm{T}}$ (Colwellia hornerae); and 5, strain ACAM 179 (Colwellia psychrotropica). Colwellia psychrerythraea and Colwellia demingiae were closely related with DNA-DNA reassociation levels ranging from 35 to $40 \%$ between the strains. Other combinations of genospecies exhibited DNA-DNA hybridization 
Table 3. DNA-DNA reassociation values between Colwellia psychrerythraea and the Antarctic Colwellia strains

$\mathrm{G}+\mathrm{C}$ content and DNA-DNA hybridization values are based on the mean of triplicate analyses $(\mathrm{SD} \pm 0 \cdot 3-0 \cdot 6 \mathrm{~mol} \%$ and $\pm 5-15 \%$, respectively).

\begin{tabular}{|c|c|c|c|c|c|c|}
\hline \multirow[t]{2}{*}{ Species } & \multirow[t]{2}{*}{$\mathbf{G}+\mathbf{C}(\mathbf{m o l} \%)$} & \multicolumn{5}{|c|}{ Percentage DNA-DNA hybridization } \\
\hline & & $\begin{array}{c}\text { ACAM } \\
5^{550^{T}}\end{array}$ & $\begin{array}{c}\mathrm{ACAM} \\
605\end{array}$ & $\begin{array}{c}\text { ACAM } \\
4_{459^{T}}\end{array}$ & $\begin{array}{c}\mathrm{ACAM} \\
608^{\mathrm{T}}\end{array}$ & $\begin{array}{c}\text { ACAM } \\
607^{T}\end{array}$ \\
\hline Colwellia psychrerythraea ACAM $550^{\mathrm{T}}$ & 38 & 100 & 85 & 35 & 13 & 12 \\
\hline Colwellia psychrerythraea ACAM 605 & 36 & 85 & 100 & 40 & 14 & 14 \\
\hline Colwellia psychrerythraea ACAM 604 & 36 & 79 & 85 & - & - & - \\
\hline Colwellia psychrerythraea IC064 & 35 & 93 & 91 & - & - & - \\
\hline Colwellia demingiae ACAM $459^{\mathrm{T}}$ & 37 & 35 & 40 & 100 & 21 & 21 \\
\hline Colwellia demingiae ACAM 606 & 37 & 38 & - & 79 & - & - \\
\hline Colwellia rossensis ACAM $608^{\mathrm{T}}$ & 38 & 13 & 14 & 21 & 100 & 22 \\
\hline Colwellia hornerae ACAM $607^{\mathrm{T}}$ & 39 & 12 & 14 & 21 & 22 & 100 \\
\hline Colwellia psychrotropica ACAM $179^{\mathrm{T}}$ & 42 & 12 & - & - & 24 & 18 \\
\hline
\end{tabular}

Table 4. Whole-cell fatty acid profiles of Colwellia psychrerythraea and novel Antarctic Colwellia species

\begin{tabular}{|lccccc|}
\hline Fatty acid* & \multicolumn{5}{c|}{ Fatty acid composition (\% of total) $\dagger$} \\
\cline { 2 - 5 } & $\begin{array}{c}\text { Colwellia } \\
\text { psychrerythraea }\end{array}$ & $\begin{array}{c}\text { Colwellia } \\
\text { demingiae }\end{array}$ & $\begin{array}{c}\text { Colwellia } \\
\text { rossensis }\end{array}$ & $\begin{array}{c}\text { Colwellia } \\
\text { hornerae }\end{array}$ & $\begin{array}{c}\text { Colwellia } \\
\text { psychrotropica }\end{array}$ \\
\hline $14: 0$ & $5 \cdot 1-7 \cdot 8$ & $7 \cdot 6-8 \cdot 0$ & $4 \cdot 6$ & $3 \cdot 0$ & $0 \cdot 8$ \\
$14: 1 \omega 7 c$ & $5 \cdot 1-7 \cdot 3$ & $9 \cdot 1-9 \cdot 3$ & $2 \cdot 8$ & $2 \cdot 8$ & $2 \cdot 0$ \\
$15: 1 \omega 8 c$ & $0-2 \cdot 3$ & $1 \cdot 9-2 \cdot 6$ & $4 \cdot 1$ & $20 \cdot 3$ & $4 \cdot 2$ \\
$15: 1 \omega 6 c$ & $0-0 \cdot 4$ & - & - & $1 \cdot 1$ & $0 \cdot 1$ \\
$15: 0$ & $1 \cdot 7-11 \cdot 0$ & $0 \cdot 9-1 \cdot 4$ & $2 \cdot 9$ & $14 \cdot 3$ & $2 \cdot 7$ \\
i16:0 & $0-0 \cdot 2$ & - & - & $10 \cdot 3$ & - \\
$16: 1 \omega 9 c$ & $6 \cdot 2-8 \cdot 8$ & $9 \cdot 5-11 \cdot 8$ & $1 \cdot 8$ & $2 \cdot 0$ & - \\
$16: 1 \omega 7 c$ & $31 \cdot 4-36 \cdot 3$ & $37 \cdot 5-37 \cdot 8$ & $43 \cdot 4$ & $15 \cdot 4$ & $56 \cdot 8$ \\
$16: 0$ & $26 \cdot 8-33 \cdot 2$ & $21 \cdot 9-23 \cdot 6$ & $27 \cdot 1$ & $13 \cdot 5$ & $21 \cdot 9$ \\
$17: 1 \omega 8 c$ & $0-1 \cdot 3$ & TR & $0 \cdot 5$ & $5 \cdot 6$ & $4 \cdot 5$ \\
$17: 1 \omega 6 c$ & $0-0 \cdot 9$ & - & - & $1 \cdot 9$ & $0 \cdot 9$ \\
$17: 0$ & $0-1 \cdot 3$ & TR & $0 \cdot 1$ & $2 \cdot 5$ & $1 \cdot 5$ \\
$18: 1 \omega 9 c$ & $0-1 \cdot 7$ & TR-0.2 & $0 \cdot 8$ & $1 \cdot 4$ & $0 \cdot 3$ \\
$18: 1 \omega 7 c$ & $0 \cdot 3-2 \cdot 1$ & $1 \cdot 3-1 \cdot 4$ & $4 \cdot 2$ & - & $1 \cdot 9$ \\
$18: 0$ & $0 \cdot 1-2 \cdot 4$ & $0 \cdot 2-0 \cdot 5$ & TR & $2 \cdot 0$ & $0 \cdot 4$ \\
$20: 5 \omega 3$ & $0-1 \cdot 5$ & -5 & TR & - & $0 \cdot 1$ \\
$22: 6 \omega 3$ & $5 \cdot 5-8 \cdot 0$ & $1 \cdot 7-2 \cdot 2$ & $6 \cdot 0$ & $2 \cdot 1$ & $0 \cdot 7$ \\
Other & $1 \cdot 7-2 \cdot 6$ & $3 \cdot 6-4 \cdot 1$ & $1 \cdot 6$ & $1 \cdot 2$ & $1 \cdot 3$ \\
\hline
\end{tabular}

* The following fatty acids were present at levels of $<1 \%$ of total fatty acid content in all species: $\mathrm{i} 13: 0, \mathrm{i} 14: 0,14: 1 \omega 5 c, \mathrm{i} 17: 0$ and $\mathrm{i} 17: 1 \omega 7 c$.

† TR, Trace fatty acid component making up $0 \cdot 1 \%$ or less of total fatty acid content.

equivalent to background reassociation levels (Table $3)$.

\section{Whole-cell fatty acid profiles}

The predominating fatty acid components detected in extracts are shown in Table 4. $\mathrm{C}_{14}-\mathrm{C}_{16}$ monounsaturated and saturated fatty acids made up the bulk of total fatty acids. Relative levels of several fatty acids varied considerably among strains, including $15: 1 \omega 8 c, 15: 0$ and $16: 1 \omega 9 c$. These fatty acids may represent labile pools within cells. The relative abundance of these fatty acid pools may be strongly influenced by the overall metabolic state and age of the culture. All strains contained DHA with some strains also forming trace levels of EPA (Table 4). 


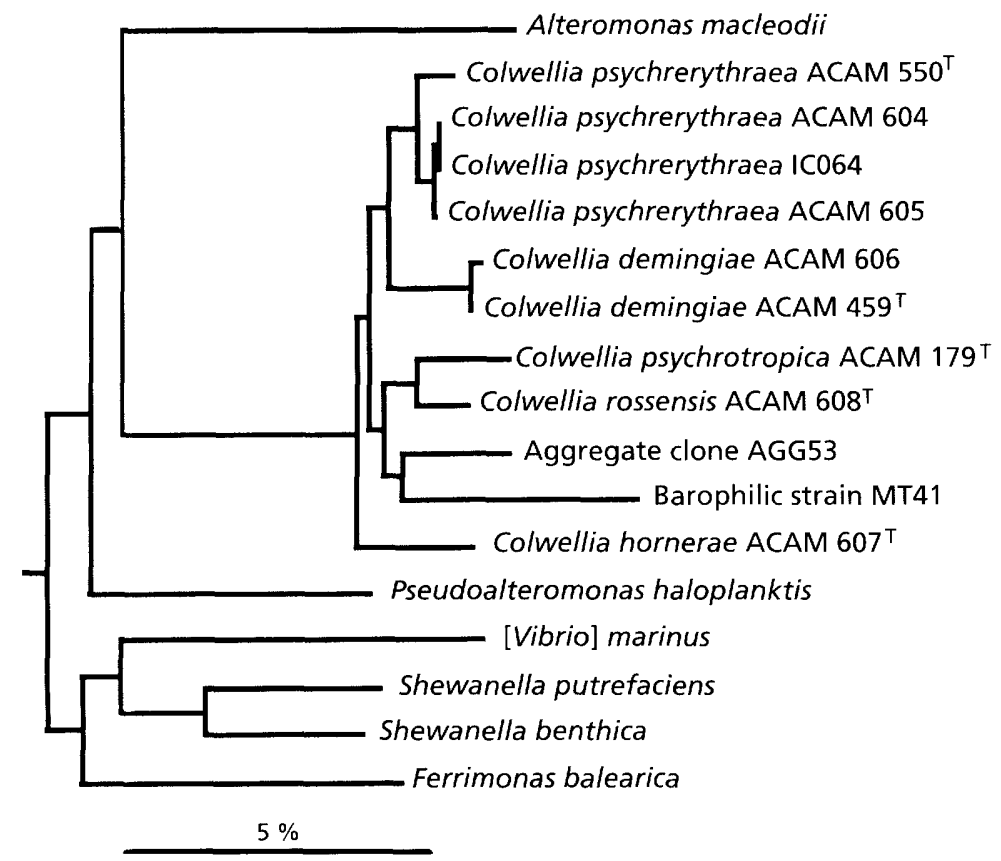

Fig. 2. Phylogenetic tree based on 165 rRNA sequence comparison showing the positions of members of the genus Colwellia within the Colwellia assemblage radiation of the $\gamma$-subclass of the Proteobacteria. Bar is equivalent to $5 \%$ sequence dissimilarity.

\section{Phylogenetic analyses}

16S rRNA sequence data indicated the Antarctic isolates were closely related to Colwellia psychrerythraea (Fig. 2). The next closest relatives were species of the genera Pseudoalteromonas and Alteromonas with sequence similarities of $87 \cdot 1-89 \cdot 3 \%$. The sequence similarity levels reflected DNA-DNA reassociation values with Colwellia psychrerythraea strains ACAM 550" , ACAM 604, ACAM 605 and IC064 and the strain pair ACAM $459^{\mathrm{T}}$ and ACAM 606 (Colvellia demingiae) each forming tight clusters with similarities of $99 \cdot 0-99 \cdot 1$ and $99 \cdot 8 \%$, respectively. The remaining strains, including ACAM $607^{\mathrm{T}}$, ACAM $608^{\mathrm{T}}$ and $A C A M 179^{\mathrm{T}}$, possessed sequence similarities of $95 \cdot 1-97 \cdot 8 \%$ with other Colwellia strains (Fig. 2).

\section{DISCUSSION}

Bacterial communities associated with Antarctic fast sea-ice diatom assemblages are dominated by Gramnegative, psychrophilic bacterial species (Gosink \& Staley, 1995; Bowman et al., 1997a) and the majority of sea-ice bacterial taxa so far cultivated are concentrated in the $\gamma$-subclass of the Proteobacteria and in the family Flavobacteriaceae. Non-pigmented, facultatively anaerobic strains were amongst those isolated and included novel species belonging to the genus Shewanella (Bowman et al., 1997b) and a number of Vibrio-like strains. Several of the Vibrio-like strains were later revealed by $16 \mathrm{~S}$ rRNA sequence analysis to belong to the genus Colwellia (Bowman et al., 1997a).

Colwellia species appear to be widely distributed in coastal (DeLong et al., 1993; Bowman et al., 1997a; Suzuki et al., 1997) and abyssal oceanic regions (Deming et al., 1984; DeLong et al., 1997) charac- terized by permanently low temperatures. The colonization of constantly low temperature and/or high-pressure marine environments by Colwellia species has been proposed to be made possible by their ability to synthesize DHA (DeLong \& Yayanos, 1986). DHA, along with other PUFAs, help to maintain the homeoviscosity of cellular membranes under low temperature and high hydrostatic pressure (Nichols et al., 1995). It was generally believed up to 5-10 years ago that prokaryotes did not contain PUFAs. DHA is now know to be formed by bacterial strains isolated from deep-sea habitats, including water columns, benthic sediments, amphipods and in deep-sea fish intestines (DeLong \& Yayanos, 1986; Yano et al., 1994; Hamamoto et al., 1995; DeLong et al., 1997). EPA- and DHA-producing bacteria often occupy the same low temperature/high pressure environmental niches, such as sea ice and the deep-sea benthos. In these environments they may supply PUFAs necessary for the normal development of metazoa (DeLong \& Yayanos, 1986; Craigschmidt et al., 1996), which generally lack the ability to synthesize $C_{20}$ and $C_{22}$ PUFAs de novo.

Preliminary evidence suggests that with a decrease in $T_{\text {opt }}$ there is a corresponding increase in the level of DHA. ACAM $179^{\mathrm{T}}$, which possesses the highest determined $T_{\text {opt }}$ of the strains in this study, has a DHA level of $0.7 \%$, while the more highly psychrophilic strains, including Colwellia psychrerythraea ACAM $550^{\mathrm{T}}$, ACAM 604, ACAM 605, IC064 and Colwellia rossensis ACAM $608^{\mathrm{T}}\left(T_{0 \mathrm{t}} 10-12{ }^{\circ} \mathrm{C}\right)$ have DHA levels ranging from 5 to $8 \%$ (Table 4 ). The inherent $T_{\text {opt }}$ and relative levels of EPA found in Shewanella species correlate in a similar way (Bowman et al., 1997b). This hypothesis can be indirectly supported by available information. To begin with, cold adaptation 
Table 5. Characteristics useful in differentiating Colwellia species and [Vibrio] marinus

+ , All strains positive for test; $v$, variable reactions for test; - , all strains negative for test; ND, no data available; NG, no growth on test medium.

\begin{tabular}{|c|c|c|c|c|c|c|c|c|c|c|c|c|}
\hline \multirow[t]{2}{*}{ Species } & \multirow{2}{*}{$\begin{array}{c}\text { Growth at } \\
25{ }^{\circ} \mathrm{C}\end{array}$} & \multicolumn{6}{|c|}{ Hydrolysis of: } & \multicolumn{2}{|c|}{ Production of acid from: } & \multirow{2}{*}{$\begin{array}{c}\text { Gas } \\
\text { vesicles }\end{array}$} & \multirow{2}{*}{$\begin{array}{c}\text { Barophilic } \\
\text { growth }\end{array}$} & \multirow{2}{*}{$\begin{array}{c}G+C \\
(\mathrm{~mol} \%)\end{array}$} \\
\hline & & Chitin & Starch & Uric acid & Urease & Tween 80 & Gelatin & Glucose & Maltose & & & \\
\hline Colwellia psychrerythraea & - & + & + & - & - & + & $\mathrm{v}$ & + & + & - & - & $35-38$ \\
\hline Colwellia hadaliensis* & - & + & ND & ND & $\mathrm{ND})$ & ND & ND & + & ND & - & + & 46 \\
\hline Colwellia demingiae & - & + & + & - & - & - & - & - & - & - & - & 37 \\
\hline Colwellia rossensis & - & + & + & - & + & $\mathrm{NG}$ & - & + & - & $+\uparrow$ & - & 38 \\
\hline Colwellia hornerae & - & - & + & - & - & + & - & - & - & - & - & 39 \\
\hline Colwellia psychrotropica & + & + & - & + & + & + & - & - & - & - & - & 42 \\
\hline [Vibrio] marinust & - & + & - & ND & $\mathrm{ND}$ & + & + & + & - & - & $\mathrm{v}$ & 42 \\
\hline
\end{tabular}

* Data from Deming et al. (1988).

$\dagger$ Colwellia rossensis is also non-motile.

† Data from Baumann et al. (1984) and DeLong \& Yayanos (1986).

is independent of growth rate, i.e. psychrotrophs grow just as well as psychrophiles at the same low temperatures (Nichols et al., 1995). In sea-ice environments the in situ temperature is constantly subzero, so cold adaptation in sea-ice Colwellia species may manifest (amongst other effects) as elevated DHA levels. Colwellia psychrotropica differs from the other Colwellia species in that it was isolated from Burton Lake which has an annual in situ temperature of about $5{ }^{\circ} \mathrm{C}$ (Franzmann et al., 1990). This has presumably resulted in less cold adaptation and thus lower DHA levels in Colwellia psychrotropica. Recent data indicates that lowering the incubation temperature results in a proportionally similar increase in PUFA levels in various bacterial strains (Hamamoto et al., 1995; Nichols \& Russell, 1996; Nichols et al., 1997). Recent evidence also shows that Colwellia species possess exoenzyme and ectoenzyme (proteases, amylases, lipases, $\beta$-galactosidase, etc.) catalytic rates with low $T_{\text {opt }}$ values and that Colwellia psychrotropica possesses uniformly higher enzyme $T_{\text {opt }}$ values compared to other tested Colwellia species (Buia, 1997).

16S rRNA-based phylogenetic analysis revealed that the sequence similarities between the Colwellia strain groups, defined by DNA hybridization experiments (Table 3) range from 95.1 to $97.8 \%$ (Fig. 2). This places a number of strains outside the estimated level of $16 \mathrm{~S}$ rRNA sequence similarity $(\geqslant 97 \%)$, potentially indicative of a species level relationship (Stackebrandt \& Goebel, 1994). The genospecies can also be differentiated clearly by phenotypic tests and DNA base composition (Table 5). It is thus proposed that each genospecies making up the genus Colwellia as defined in this study on the basis of polyphasic taxonomic analyses represents a distinct and novel species. On this basis four new species are proposed to be included in the genus Colwellia with the following names: Colwellia demingiae sp. nov., Colwellia hornerae sp. nov., Colwellia rossensis sp. nov. and Colwellia psychrotropica $\mathrm{sp}$. nov. The genus Colwellia also includes the type species Colwellia psychrerythraea and the obligately barophilic species Colwellia hadaliensis.

\section{Description of Colwellia demingiae sp. nov.}

Colwellia demingiae (de.ming'i.ae. L. adj. demingiae in honour of Jody W. Deming, an American microbiologist who has expanded knowledge of deep-sea bacteria).

Gram-negative. Individual cells are straight to curved rods, with spherical and short filamentous cells occasionally occurring. Length $1 \cdot 5-4.5 \mu \mathrm{m}$, width 0.4-0.6 $\mu \mathrm{m}$. Gas vesicles not formed. Motile. Colonies are off-white, have a mucoid consistency, raised elevation and convex circular shape with entire to lobate edges. Psychrophilic. In liquid media $T_{\text {opt }}$ is approximately $10-12^{\circ} \mathrm{C}$ and $T_{\max }$ is about $18^{\circ} \mathrm{C}$. Requires sea salts for growth. Growth factors are not required. Facultatively anaerobic chemoheterotroph. Acid (with no gas) is formed fermentatively and oxidatively from chitin and $N$-acetylglucosamine. Casein, aesculin, chitin and starch are hydrolysed. The following compounds are utilized as sole sources of carbon and energy: $N$-acetylglucosamine, acetate, propionate, butyrate, valerate, caproate, succinate, glutarate, citrate, fumarate, pyruvate, DL-lactate, oxaloacetate, L-asparagine, L-glutamate, L-proline, Lserine and $\gamma$-aminobutyrate. Some strains can also utilize glycogen, isobutyrate, heptanoate, caprylate, malonate, azelate, L-alanine, L-aspartate, L-phenylalanine and hydroxy-L-proline. $\mathrm{G}+\mathrm{C}$ content is $37 \mathrm{~mol} \%\left(T_{\mathrm{m}}\right)$. Isolated from fast sea ice of the Prydz Bay coast, Antarctica. Type strain is ACAM $459^{\mathrm{T}}$.

\section{Description of Colwellia hornerae sp. nov.}

Colwellia hornerae (hor.ner'ae. L. adj. hornerae in honour of Rita Horner, an American biologist who pioneered studies on sea-ice microbiota). 
Gram-negative. Individual cells are straight to curved rods, with spherical cells occasionally occurring. Length $1 \cdot 5-3.0 \mu \mathrm{m}$, width $0.4-0.8 \mu \mathrm{m}$. Gas vesicles not formed. Motile. Colonies are off-white, have a mucoid consistency, raised elevation and convex circular shape with entire to lobate edges. Psychrophilic. In liquid media $T_{\text {opt }}$ is approximately $12^{\circ} \mathrm{C}$ and $T_{\max }$ is about $23-24{ }^{\circ} \mathrm{C}$. Requires sea salts for growth. Growth factors not required. Sensitive to vibriostatic agent $\mathrm{O} / 129\left(100 \mu \mathrm{g} \mathrm{ml}^{-1}\right)$. Facultatively anaerobic chemoheterotroph. Acid (but no gas) is formed fermentatively and oxidatively from L-rhamnose. Acid is formed oxidatively from glycerol. Tween 80 , casein, aesculin and starch are hydrolysed. The following compounds are utilized as sole sources of carbon and energy: glycerol, acetate, propionate, butyrate, valerate, caproate, heptanoate, succinate, glutarate, azelate, citrate, fumarate, pyruvate, DL-lactate, oxaloacetate, $\mathrm{L}$-glutamate, $\mathrm{L}$-proline, hydroxy-L-proline and $\gamma$-aminobutyrate. $\mathrm{G}+\mathrm{C}$ content is $39 \mathrm{~mol} \%\left(T_{\mathrm{m}}\right)$. Isolated from fast sea ice of the Prydz Bay coast, Antarctica. Species is monotypic. Type strain is ACAM $607^{\mathrm{T}}$.

\section{Description of Colwellia rossensis sp. nov.}

Colwellia rossensis (ross.en'sis. M.L. fem. adj. rossensis from the Ross Sea, Antarctica).

Gram-negative. Individual cells are straight to curved rods, with spherical cells occasionally occurring. Length $1 \cdot 5-3 \cdot 0 \mu \mathrm{m}$, width $0 \cdot 4-0 \cdot 8 \mu \mathrm{m}$. Gas vesicles are formed. Non-motile. Colonies are chalky-white, have a raised elevation and convex circular shape with entire edges. Psychrophilic. In liquid media $T_{\text {opt }}$ is approximately $10^{\circ} \mathrm{C}$ and $T_{\max }$ is about $15^{\circ} \mathrm{C}$. Requires sea salts for growth. Yeast extract required for growth. Facultatively anaerobic chemoheterotroph. Acid (but no gas) is formed fermentatively and oxidatively from chitin, $N$-acetylglucosamine and D-glucose. Also produces acid oxidatively from D-galactose and glycerol. Urea, chitin and starch are hydrolysed. The following compounds are utilized as sole sources of carbon and energy: glycogen, L-arabinose, $N$-acetylglucosamine, D-fructose, D-glucose, glycerol, Dgluconate, acetate, butyrate, valerate, caproate, malonate, succinate, citrate, 3-hydroxybutyrate, Lmalate, fumarate, pyruvate, L-alanine, L-aspartate, $\mathrm{L}$-asparagine, L-glutamate, L-proline and $\gamma$-aminobutyrate. $\mathrm{G}+\mathrm{C}$ content is $38 \mathrm{~mol} \%\left(T_{\mathrm{m}}\right)$. Isolated from the sea/ice interface of fast sea ice, McMurdo Sound Antarctica (Gosink \& Staley, 1995). Species is monotypic. Type strain is ACAM $608^{\mathrm{T}}$.

\section{Description of Colwellia psychrotropica sp. nov.}

Colwellia psychrotropica (psy.chro.tro.pi'ca. Gr. adj. psychros cold; Gr. n. tropica tropic, circle; M.L. fem. adj. psychrotropica having an affinity for cold).

Gram-negative. Individual cells are straight to curved rods, with spherical cells occasionally occurring. Length 1.5-3.0 $\mu \mathrm{m}$, width 0.4-0.8 $\mu \mathrm{m}$. Motile. Colonies are off-white, have a mucoid consistency, raised elevation and convex circular shape with entire to lobate edges. In liquid media $T_{\text {opt }}$ is approximately $18{ }^{\circ} \mathrm{C}$ and $T_{\max }$ is about $26^{\circ} \mathrm{C}$. Requires sea salts for growth. Growth factors not required. Growth occurs in the presence of sea salts at three times normal concentration and is resistant to vibriostatic agent $\mathrm{O} / 129\left(100 \mu \mathrm{g} \mathrm{ml}^{-1}\right)$. Facultatively anaerobic chemoheterotroph. Acid (but no gas) is formed fermentatively and oxidatively from chitin and $\mathrm{N}$-acetylglucosamine. Urea, uric acid, Tween 80 , casein, chitin and L-tyrosine are degraded. The following compounds are utilized as sole sources of carbon and energy: $N$-acetylglucosamine, acetate, butyrate, valerate, caproate, succinate, 2-oxoglutarate, 3hydroxybutyrate, L-malate, fumarate, pyruvate, DLlactate, oxaloacetate, L-alanine, L-aspartate, L-asparagine, L-glutamate, L-proline and $\gamma$-aminobutyrate. $\mathrm{G}+\mathrm{C}$ content is $42 \mathrm{~mol} \%\left(T_{\mathrm{m}}\right)$. Isolated from the pycnocline of an Antarctic marine salinity meromictic lake (Burton Lake). Species is monotypic. Type strain is $\mathrm{ACAM} 179^{\mathrm{T}}$.

\section{ACKNOWLEDGEMENTS}

This research was supported by grants from the Antarctic Research Council, the Antarctic Science Advisory Committee (grants no. 865 and 1012), Australian Postgraduate Award system (for D.S.N., S.A.M. and T.E.L.) and Australian Research Council APD (for D.S.N.). Partial funding came from an NSF grant (BSR 90006788). We thank Carol Mancuso (ACAM) for culture preservation and Phyllis Pienta (ATCC) for provision of the type culture of Colwellia psychrerythraea.

\section{REFERENCES}

Baumann, P., Furniss, A. L. \& Lee, J. V. (1984). Genus I. Vibrio Pacini 1854, 411 ${ }^{\mathrm{AL}}$. In Bergey's Manual of Systematic Bacteriology, vol. 1, pp. 518-538. Edited by N. R. Krieg \& J. G. Holt. Baltimore: Williams \& Wilkins.

Bowman, J. P., Austin, J. J., Cavanagh, J. \& Sanderson, K. (1996). Novel Psychrobacter species from Antarctic ornithogenic soils. Int $J$ Syst Bacteriol 46, 841-848.

Bowman, J. P., McCammon, S. A., Brown, M. V. \& McMeekin, T. A. (1997a). Diversity and association of psychrophilic bacteria in Antarctic sea ice. Appl Environ Microbiol 63, 3068-3078.

Bowman, J. P., McCammon, S. A., Nichols, D. S., Skerratt, J. H., Rea, S. M., Nichols, P. D. \& McMeekin, T. A. (1997b). Novel species of Shewanella isolated from Antarctic sea ice with the ability to produce eicosapentaenoic acid $(20: 5 \omega 3)$ and grow anaerobically by dissimilatory $\mathrm{Fe}(\mathrm{III})$ reduction. Int $J$ Syst Bacteriol 47, 1040-1047.

Buia, A. D. (1997). Production of cold adapted enzymes by Antarctic sea ice bacteria. Honours thesis. Institute of Antarctic and Southern Ocean Studies, University of Tasmania.

Craigschmidt, M. C., Stieh, K. E. \& Lien, E. L. (1996). Retinal fatty acids of piglets fed docosahexaenoic and arachidonic acids from microbial sources. Lipids 3, 53-59.

D'Aoust, J. Y. \& Kushner, D. J. (1972). Vibrio psychroerythrus sp. n.: classification of the psychrophilic marine bacterium, NRC 1004. J Bacteriol 111, 340-342.

DeLong, E. F. \& Yayanos, A. A. (1986). Biochemical function and 
ecological significance of novel bacterial lipids in deep-sea procaryotes. Appl Environ Microbiol 51, 730-737.

DeLong, E. F., Franks, D. G. \& Alldredge, A. L. (1993). Phylogenetic diversity of aggregate-attached vs. free-living marine bacterial assemblages. Limnol Oceanogr 38, 924-934.

DeLong, E. F., Franks, D. G. \& Yayanos, A. A. (1997). Evolutionary relationships of cultivated psychrophilic and barophilic deepsea bacteria. Appl Environ Microbiol 63, 2105-2108.

Deming, J. W., Hada, H., Colwell, R. R., Luehrsen, K. R. \& Fox, G. R. (1984). The ribonucleotide sequence of $5 \mathrm{~S} r \mathrm{RNA}$ from two strains of deep-sea barophilic bacteria. J Gen Microbiol 130 , 1911-1920.

Deming, J. W., Somers, L. K., Straube, W. L., Swartz, D. G. \& MacDonell, M. T. (1988). Isolation of an obligately barophilic bacterium and description of a new genus, Colwellia gen. nov. Syst Appl Microbiol 10, 152-160.

Euzéby, J. P. (1998). Taxonomic note: necessary correction of specific and subspecific epithets according to Rules 12c and 13b of the International Code of Nomenclature of Bacteria (1990 Revision). Int J Syst Bacteriol 48, 1073-1075.

Farkas, K., Ratchford, I. A. J., Noble, R. C. \& Speake, B. K. (1996). Changes in the size and docosahexaenoic acid content of adipocytes during chick embryo development. Lipids 31, 313-321

Felsenstein, J. (1993). PHYLIP (phylogeny inference package), version $3.57 \mathrm{c}$. Seattle: University of Washington.

Franzmann, P. D., Deprez, P. P., McGuire, A. J., McMeekin, T. A. \& Burton, H. R. (1990). The heterotrophic bacterial microbiota of Burton Lake, Antarctica. Polar Biol 10, 261-264.

Gauthier, G., Gauthier, M. \& Christen, R. (1995). Phylogenetic analysis of the genera Alteromonas, Shewanella and Moritella using genes coding for small-subunit rRNA sequences and division of the genus Alteromonas into two genera, Alteromonas (emended) and Pseudoalteromonas gen. nov. and proposal of twelve new species combinations. Int $J$ Syst Bacteriol 45 , 755-761.

Gosink, J. J. \& Staley, J. T. (1995). Biodiversity of gas vacuolate bacteria from Antarctic sea ice and water. Appl Environ Microbiol 61, 3486-3489.

Hamamoto, T., Takata, N., Kudo, T. \& Horikoshi, K. (1995). Characteristic presence of polyunsaturated fatty acids in marine psychrophilic vibrios. FEMS Microbiol Lett 129, 51-56.

Hungate, R. E. (1968). A roll tube method for cultivation of strict anaerobes. Methods Microbiol 3B, 117-132.

Huss, V. A. R., Festl, H. \& Schleifer, K.-H. (1983). Studies on the spectrophotometric determination of DNA hybridization from renaturation rates. Syst Appl Microbiol 4, 184-192.

Kelly, F. J. (1991). The metabolic role of n-3 PUFA: relationship to human disease. Comp Biochem Physiol 98, 581-585.

Linko, Y. Y. \& Hayakawa, K. (1996). Docosahexaenoic acid - a valuable nutraceutical. Trends Food Sci Technol 7, 59-63.

Lovely, D. R. \& Phillips, E. J.P. (1986). Organic matter mineralization with reduction of ferric iron in anaerobic sediments. Appl Environ Microbiol 54, 683-689.

Marmur, J. \& Doty, P. (1962). Determination of the base composition of deoxyribonucleic acid from its thermal denaturation temperature. J Mol Biol 5, 109-118.

Nichols, D. S. \& Russell, N. J. (1996). Fatty acid adaptation in an Antarctic bacterium - changes in primer utilization. Microbiology 142, 747-754.

Nichols, D. S., Nichols, P. D. \& McMeekin, T. A. (1993). Poly- unsaturated fatty acids in Antarctic bacteria. Antarct $S_{c i} \mathbf{5}$, 149-160.

Nichols, D. S., Nichols, P. D. \& McMeekin, T. A. (1995). Ecology and physiology of psychrophilic bacteria from Antarctic saline lakes and sea ice. Sci Prog 78, 311-347.

Nichols, D. S., Hart, P., Nichols, P. D. \& McMeekin, T. A. (1996). Enrichment of the rotifer Brachionus plicatilis fed an Antarctic bacterium containing polyunsaturated fatty acids. Aquaculture 147, 115-125.

Nichols, D. S., Brown, J. L., Nichols, P. D. \& McMeekin, T. A. (1997). Production of eicosapentaenoic acid and arachidonic acids by an Antarctic bacterium: response to growth temperature. FEMS Microbiol Lett 152, 349-354.

Nichols, P. D., Guckert, J. B. \& White, D. C. (1986). Determination of monounsaturated fatty acid double-bond position and geometry for microbial monocultures and complex consortia by capillary GC-MS of their dimethyldisulphide adducts. $J$ Microbiol Methods 5, 49-55.

Ostrowski, A. C. \& Divakaran, S. (1990). Survival and bioconversion of $\mathrm{n}-3$ fatty acids during early development of dolphin (Coryphaena hippurus) larvae fed oil-enriched rotifers. Aquaculture 89, 273-285.

Overmann, J. \& Pfennig, N. (1989). Pelodictyon phaeoclathratiforme sp. nov., a new brown-colored member of the Chlorobiaceae forming net-like colonies. Arch Microbiol 152, 401-406.

Ratkowsky, D. A., Lowry, R. K., McMeekin, T. A., Stokes, A. N. \& Chandler, R. E. (1983). Model for bacterial growth throughout the entire biokinetic range. $J$ Bacteriol 154, 1222-1226.

Rossello-Móra, R. A., Ludwig, W., Kämpfer, P., Amann, R. \& Schleifer, K.-H. (1995). Ferrimonas balearica gen. nov., a new marine facultative Fe(III)-reducing bacterium. Syst Appl Microbiol 18, 196-202.

Sly, L. I., Blackall, L. L., Kraat, P. C., Tian-Shen, T. \& Sangkhobol, V. (1986). The use of second derivative plots for the determination of $\mathrm{mol} \%$ guanine plus cytosine of DNA by the thermal denaturation method. J Microbiol Methods 5, 139-156.

Southgate, P. C. \& Lou, D. C. (1995). Improving the n-3 PUFA composition of Artemia using microcapsules containing marine oils. Aquaculture 134, 91-99.

Stackebrandt, E. \& Goebel, B. M. (1994). Taxonomic note: a place for DNA-DNA reassociation and 16 S rRNA sequence analysis in the present species definition in bacteriology. Int $J$ Syst Bacteriol 44, 846-849.

Staley, J. T., Fuerst, J. A., Giovannoni, S. \& Schlesner, H. (1992). The order Planctomycetales and the genera Planctomyces, Pirellula, Gemmata and Isosphaera. In The Prokaryotes, vol. IV, pp. 3710-3731. Edited by A. Balows, H. G. Trüper, M. Dworkin, W. Harder \& K.-H. Schleifer. New York: Springer.

Suzuki, M. T., Rappé, M. S., Haimberger, Z. W., Winfield, H., Adair, N., Ströbel, J. \& Giovannoni, S. J. (1997). Bacterial diversity among small-subunit rRNA gene clones and cellular isolates from the same seawater sample. Appl Environ Microbiol 63, 983-989.

Widdel, F. \& Bak, F. (1992). Gram-negative mesophilic sulfatereducing bacteria. In The Prokaryotes, vol. 4, pp. 3352-3378. Edited by A. Balows, H. G. Trüper, M. Dworkin, W. Harder \& K.-H. Schleifer. New York: Springer.

Yano, Y., Nakayama, A., Saito, H. \& Ishihara, K. (1994). Production of docosahexaenoic acid by marine bacteria isolated from deep sea fish. Lipids 29, 527-528.

ZoBell, C. E. (1946). Marine Microbiology. Waltham, MA: Chronica Botanica. 